\title{
Hurricane Lilies, Lycoris Species, in Florida ${ }^{1}$
}

Gary W. Knox ${ }^{2}$

Hurricane lilies, Lycoris species, are bulbs that flower suddenly after heavy summer rains in August and September. Their common name in Florida, hurricane lily, results from their blooming period coinciding with the height of the hurricane season. Other common names for Lycoris species are spider lily, surprise lily, magic lily, resurrection lily, naked lady, schoolhouse lily, and Guernsey lily. Hurricane lilies are members of the Amaryllis Family, which includes other well-known bulbs such as amaryllis (Hippeastrum spp.), daffodils (Narcissus spp.), rain lilies (Zephyranthes and Habranthus spp.) and snowdrops (Leucojum spp.).

\section{Hurricane Lilies in the Garden}

Hurricane lilies are easy to grow in north and central Florida. Bulbs should be planted so the "neck" is just below the soil surface. Dormant bulbs are best planted during late summer and fall, whereas actively growing plants can be planted other times of the year. Hurricane lilies thrive in sunny to partially sunny areas such as the edges of woodlands and shrub borders or under deciduous trees. These sites also help protect the fragile flowers from wind and sun. Hurricane lilies do not require fertilizer or irrigation, but grow best in rich, moist soil.
The types of hurricane lily that grow best in Florida have long, narrow leaves that emerge in fall, persist through winter, and die down in spring. The clumps of blue-green foliage resemble liriope (Liriope spp.) but with a pale stripe down the center of each leaf. Leaves turn yellow in spring and should be allowed to die naturally. Cutting back leaves while they are yellowing will harm the bulb and reduce flowering. No leaves are present during summer months when bulbs are dormant.

\section{Surprise Flowering}

In August and September after a heavy rain (it doesn't have to be a hurricane), flowers appear almost magically since there is no foliage to indicate where the bulb is planted (thus providing the common names, magic lily and surprise lily). Leafless stems emerge and quickly grow 12 to 24 or more inches tall before being topped by 8 -inch clusters of 5 to 7 tubular flowers. Most species have flowers with narrow, strap-like petals and extremely long stamens, giving a spidery appearance to the flowers (and hence another common name, spider lily). Each cluster of flowers lasts about 2 weeks, or longer if flowers are protected from wind and sun. Each bulb can produce

1. This document is ENH1036, one of a series of the Environmental Horticulture Department, Florida Cooperative Extension Service, Institute of Food and Agricultural Sciences, University of Florida. Original publication date May, 2006. Visit the EDIS Web Site at http://edis.ifas.ufl.edu.

2. Extension Specialist and Professor of Environmental Horticulture, University of Florida/IFAS, North Florida Research and Education Center, 155 Research Road, Quincy, FL 32351.

The Institute of Food and Agricultural Sciences (IFAS) is an Equal Opportunity Institution authorized to provide research, educational information and other services only to individuals and institutions that function with non-discrimination with respect to race, creed, color, religion, age, disability, sex, sexual orientation, marital status, national origin, political opinions or affiliations. U.S. Department of Agriculture, Cooperative Extension Service, University of Florida, IFAS, Florida A. \& M. University Cooperative Extension Program, and Boards of County Commissioners Cooperating. Larry Arrington, Dean 
1 to 4 flower stems, and all bulbs typically do not flower at once, so subsequent rains often result in a sequence of flowering. Hurricane lilies make excellent cut flowers as well as beautiful garden plants.

Hurricane lilies have a reputation for inconsistent flowering from year to year. This is often caused by bulb crowding or, conversely, recent planting. Large clumps of bulbs should be divided every few years to avoid reduced growth and flowering caused by crowding. Bulb clumps are best divided in early summer when bulbs are dormant. Flowering may be delayed a year or more if clumps are divided and planted at other times of the year. Newly planted bulbs may not flower until the second year after planting, especially if roots are missing or have dried before planting.

Some hurricane lilies produce viable seeds. Unfortunately, seeds don't germinate easily and it may take 6 to 12 years for seedlings to produce bulbs large enough to flower.

\section{Ancient, Beautiful, Poisonous and Deer-Resistant}

Lycoris species have long been used as garden flowers in their native habitats of China and Japan, particularly around temples, graveyards and cultivated fields. One common name in China can be translated as "stone garlic" and another mentions the legendary Chinese ghost-catcher, Chung Kwei. The first name refers to the onion-like bulbs and the second to the poisonous components in Lycoris that would allow Chung Kwei to easily capture the ghost of any hapless bulb-eater mistaking it for garlic.

Bulbs of all Lycoris species contain the alkaloid poison, lycorine, which causes vomiting, diarrhea, convulsions and sometimes death in humans and other animals. Although Lycoris bulbs are considered to have low toxicity, homeowners should be aware of the poisonous potential of hurricane lilies, particularly if small children and pets are present. On the other hand, this poisonous component has the benefit of making hurricane lilies resistant to damage from deer and rodents. The Japanese exploited this poisonous aspect of Lycoris species by planting them along the edges of rice paddies, presumably to discourage mice.

Another alkaloid component is galantamine, which is used in medications to treat Alzheimers-type dementia. Lycoris is being grown in plantations in China for mass harvest to extract this compound.

\section{Availability}

Common hurricane lilies can be found growing in many older homesteads throughout the southeastern U.S. Interestingly, they are not widely grown in nurseries, and it may be challenging to find them. Hurricane lily bulbs are more likely to be available in summer and fall from better garden centers as well as some mail-order nurseries. Unusual Lycoris species and hybrids may be found at specialty bulb nurseries or from collectors and breeders.

\section{Widely Available Hurricane Lilies}

The most common hurricane lily is Lycoris radiata var. radiata (also known as red spider lily; Figure 1), producing red-orange flowers. This plant is a sterile triploid, preventing it from forming seeds and causing it to be free-flowering. Without the burden of producing seeds, this plant is also very fast growing, resulting in large clumps of bulbs that can be separated and planted. Lycoris radiata var. radiata is vigorous and produces bulbs so prolifically that it is far more common than its smaller, seed-producing diploid form known as Lycoris radiata var. pumila. Red spider lily has been cultivated since ancient times in China and Japan and since the early 1800s in the U.S. This plant has naturalized and is considered an "heirloom plant" in the southern U.S.

\section{Lycoris aurea (golden spider lily) produces} clusters of 4 to 7 yellow, trumpet-shaped flowers on stems 18 to 24 or more inches tall. Sturdy, bluish leaves emerge in fall and grow up to 24 inches long, producing a larger plant than red spider lily. Golden spider lily also may be sold as Lycoris traubii, an obsolete name for this species or perhaps a subspecies.

Lycoris squamigera (magic lily) may be commonly found in nursery catalogs but isn't well adapted to the heat and humidity of Florida. Its 
gray-green leaves emerge in spring and die down by early summer. Magic lily has lilac-pink, amaryllis-like flowers in July.

\section{Less Common Hurricane Lilies}

Lycoris albiflora (white spider lily) produces clusters of 6 to 8 white flowers on a stem 12 to 18 inches tall. Each petal may have a narrow creamy-pink stripe down the center, but the stripe (and flower) fades to white with age. Like red spider lily, this plant's leaves emerge in fall and die down in spring. This plant is a sterile hybrid of L. radiata and Lycoris traubii and is sometimes mislabeled as Lycoris alba.

Lycoris haywardii (surprise lily) is one of the few spring-leafing hurricane lilies that grows well in Florida. In fact, this plant was first discovered in Winter Park, Florida, in a 1948 shipment of Chinese plants to Dr. Wyndham Hayward. It develops leaves in early spring that die down in early summer. The trumpet-shaped flowers are magenta-pink with bright blue tips at the ends of petals. The plant flowers in July, often earlier than other hurricane lilies. It is believed to be a hybrid of $L$. squamigera and $L$. radiata var. pumila.

Lycoris sanguinea (orange spider lily or surprise lily) is another spider lily said to grow poorly in Florida. As with magic lily (L. squamigera), it develops leaves in early spring rather than in fall. It produces clusters of 3 to 5 orange-red flowers.

More than twenty Lycoris species are known, and there are countless hybrids, but most are not widely grown.

\section{References}

Cooke, D.A. and Phan Yen Leng. Notes on Lycoris Species. http://members.ozemail.com.au/ davcooke/ lycoris.htm Accessed July 11, 2005.

Ogden, Scott. 1994. Garden bulbs for the South. Taylor Publishing Company, Dallas, Texas.

Russell, Alice B. Poisonous plants of North Carolina.

http://www.ces.ncsu.edu/depts/hort/consumer/poison/ poison.htm North Carolina Cooperative Extension Service, North Carolina State University, Raliegh, North Carolina. Accessed July 11, 2005.

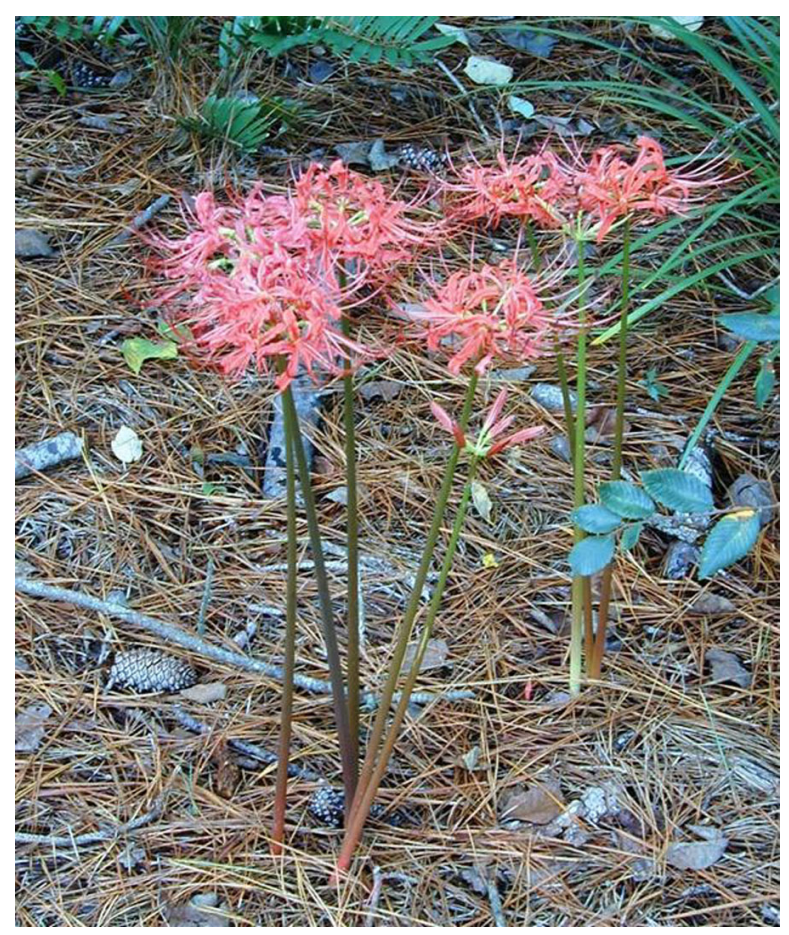

Figure 1. Red spider lily, Lycoris radiata var. radiata. 